\title{
Comparison of seed germination and seedling growth between Indonesian local corn cultivars for deciding the quality of seed
}

\author{
ALBERT HUSEIN WAWO ${ }^{1, \boldsymbol{\nu}}$, VERINA GITA SUMBOGO ${ }^{2}$, PENI LESTARI ${ }^{1}$ \\ ${ }^{1}$ Research Center for Biology, Indonesian Institute of Sciences. Jl. Raya Jakarta-Bogor Km. 46, Cibinong, Bogor 16911, West Java, Indonesia. \\ Tel.: +62-21-87907636, 87907604, Fax.: +62-21-87907612, ^email: wawoal@gmail.com \\ ${ }^{2}$ Universitas Sebelas Maret. Jl. Ir. Sutami No. 36 A, Surakarta 57126, Central Java, Indonesia
}

Manuscript received: 23 April 2020. Revision accepted: 21 June 2020.

\begin{abstract}
Wawo AH, Sumbogo VG, Lestari P. 2020. Comparison of seed germination and seedling growth between Indonesian local corn cultivars for deciding the quality of seed. Biodiversitas 21: 3189-3199. Each region in Indonesia has local corn cultivars (Zea mays L), for example, South Sulawesi has some Pulut Pangkajene cultivars and Purbalingga, Central Java has Entog and Senggani cultivars. Compared to hybrid corn, local corn has its advantages such as dry resistance, short life, and specific taste. The identification of seed germination and seedling growth for Pangkajene corn (South Sulawesi), Entog, and Senggani corns (Purbalingga) has not been performed, thus, specific characteristics to differ those three corn cultivars have not been available. The study aims to establish the characteristics of local corn cultivars, comprise the seed germination, seedling growth, and determine the best local corn cultivars for supporting food sources. This research has Factorial patterned with a Completely Randomized Design and it was repeated 4 times. The main factor is the germination facility, namely germination chamber, and nursery house. Meanwhile, the second factors are corn cultivars, namely Pangkajene, Entog, and Senggani. The result shows that the Pangkajene and Entog cultivars have higher germinability and germination value compared to Senggani corn cultivar. Pangkajene and Senggani cultivars have higher seedling growth than Entog cultivar seedlings characterized by high relative growth rate (R) values. The Pangkajene cultivar has higher quality compared to 2 local corn cultivars of Entog and Senggani from Purbalingga (Central Java). Further, Senggani cultivars have higher quality than Entog cultivars.
\end{abstract}

Keywords: Entog, germinability, local corn, Pangkejene, Senggani

\section{INTRODUCTION}

Indonesia is an agrarian country located in the equatorial region. Thus, this country has abundant biodiversity that can be used as main and supporting food sources. Over the last 4-5 decades, the population of this country has considered rice as staple foods and neglected to use other commodities such as corn, sorghum, barley, tubers, and beans as supporting food sources. Indonesian population considers eating if only they eat rice, even if they have consumed tubers or corn more than 600 grams per meal, they will not consider it 'eating'. Climate change and change of rice field function become the main reasons for the decrease of rice production every year. Therefore, the development and utilization of non-rice food commodities have to be continuously campaigned, particularly improving the cultivation system and handling post-harvest processing to produce quality and nutritionally balanced food to increase consumption. One of the local food commodities is local corn (Zea mays L).

The consumed corn is hybrid varieties thus far as its production is relatively high. Meanwhile, local corn cultivars are utilized for animal feed and the local corn is typically planted in the rice field after harvesting time and at infertile soil in the garden. Hybrid corn varieties have high productivity if supported by appropriate production factors (inputs) such as quality seeds, appropriate fertilizer, and proper irrigation. Local corn cultivars are less attractive to farmers due to their lower productivity and quality compared to hybrid corn. Wawo et al. (2018) explain that the farmers' low interest in cultivating local corn will threaten the extinction of genetic resources in the future. However, local corn cultivars have some advantages in breeding or new varieties assembling.

The advantages of local corn cultivars have not been informed thus far. The advantages are short-life, resistant to pests and diseases, dry resistance has a distinctive taste (according to local people), and sources of foods the famine season. For example, local corn from South Sulawesi, that called Pulut corn, is a local cultivar typically used as a snack and it becomes a source of income for some cafes and restaurants in this area. Further, Purbalingga District, Central Java has 2 local corn cultivars, Genjah Senggani, and Genjah Entog. However, they have not been utilized optimally as Pulut corn. Genjah Senggani can be found in Limbangan, Kutasari at an altitude of $250.0 \mathrm{~m}$ above sea level, while the Genjah Entog can be found in Kedung Wuluh, Kalimanah at an altitude of $70.0 \mathrm{~m}$ above sea level. Pulut corn cultivars typically have high amylopectin content, thus they taste sweeter, more delicious, and tastier compared to other local corns.

Currently, the Research Center for Biology, Indonesian Institute of Sciences (LIPI) has one local corn cultivar from Pangkajene, South Sulawesi, i.e. Pulut cultivar and 2 local corn cultivars from Purbalingga, Central Java, i.e. Genjah Entog, and Genjah Senggani. Although Pulut corn (Pangkajene cultivar) has been published, but information about its seeds and seedlings has not been available yet, 
neither does the local corn from Purbalingga. Seeds and seedlings information is essential as characteristic of the local corn cultivars therefore easy to treat differently between local cultivars seeds and in the future the presence of local corn seeds in seeds storage is very important as genetic stock for assembling a new variety.

This study aims to identify the characteristics of local corn cultivars and determine the best local corn cultivars through seed germinability and seedling growth. Its objective is to obtain information such as the percentage of germination, mean germination time, germination rate, and the relative seedling growth rate of the 3 local corn cultivars.

\section{MATERIALS AND METHODS}

\section{Materials}

This study was conducted at the Plant Physiology Laboratory, Botani Division, Research Center for Biology, Indonesian Institute of Sciences (LIPI), Cibinong, Bogor, Indonesia in early 2019. The material covered 3 local corn cultivars, Pulut Pangkajene (South Sulawesi), Genjah Entog, and Genjah Senggani (Purbalingga, Central Java). This research was conducted in 2 stages, namely seed characterization and seedling growth. In this paper, Pulut Pangkajene cultivar is called Pangkajene cultivar. Then, Genjah Entog is called Entog cultivar, while Genjah Senggani is called Senggani cultivar.

\section{Procedures}

Characterization of local corn seeds

The researchers selected fifty of each local corn cultivars, Pangkajene, Entog, and Senggani with uniform size and color with 3 repetitions and then weighed with an analytical balance. Then, the seeds were characterized by measuring the length, width, and thickness of ten seeds. The shape and color of the seeds were determined using Descriptors for Maize (IBPGR 1991) and RHS color chart sixth edition.

Measurement of the water content used oven method. Each local corn cultivar was weighed using an analytical balance of 3 grams in a petri dish and then they were dried in an oven at $105^{\circ} \mathrm{C}$ for 90 minutes. The drying process was done several time up to reach the constant weight. Measurement water content of each local corn seeds was repeated 3 times. Then, the seeds were inserted in a desiccator until the petri dish got cold and then the dry weight of the seeds was weighed. The seed moisture content was counted using the following equation (Sutopo 1985):

$$
\text { Moisture content of seedling }=\frac{b-c}{b-a} \times 100 \%
$$

\section{Where:}

a: Weight of container + lid

b: Weight of container + lid + sample of initial seeds

c: Weight of container + lid + sample of seeds after drying
The Indirect viability test used the Tetrazolium Test. The fifteen seeds corn from each cultivar were first soaked in water for \pm 24 hours, then they were peeled and cut into two parts so that the tetrazolium solution can easily get into the seeds, particularly the embryo. The seeds were dripped with $0.5 \%$ tetrazolium solution evenly and kept for \pm 4 hours or until the color of embryo turn to red. Thus they can be used as research materials. Seeds are categorized as living if the embryo is bright red and dead if the embryo is pale red or white.

\section{Design of seed germination and seedling growth}

Pangkajene corn seeds were collected from farmers at Pangkajene District (South Sulawesi province) in August 2012, then brought to Bogor. Seeds were stored in dry room conditions for 7 years. Entog seeds were collected from farmers at Kalimanah Village, Purbalingga District. These seeds were harvested in August 2018 and further packed in sacks and stored in a warehouse at Kalimanah Village for 4 months. Senggani corn seeds were collected from farmers at Lindungan Village, Purbalingga District. Senggani seeds were harvest at rice field last December 2018. Further, both of seeds from Purbalingga District brought to Bogor at early of January 2019.

The researchers selected identical 300 seeds of each cultivar, namely Pangkajene, Entog, and Senggani. The researchers prepared a total of 200 seeds per cultivar. Germination was carried out with 4 replications for each cultivar and 25 seeds of each replication were germinated in a germination tray. Germination tray consisted of media of a mixture of sand and soil with a ratio of $1: 1$. The germination tray was placed in two different germination facility namely in the germination chamber (100 seeds) and the nursery house (100 seeds). The seedling germination tray was watered every day to maintain the moisture and avoid drying out.

The germination research used Factorial patterns with a Completely Randomized Design of 4 replications. The main factor is germination facility which consists of two places, namely the germination chamber and nursery house (Environmental condition of germination facility in Table 1). While the second factor is the cultivars, namely Pangkajene, Entog, and Senggani. The parameters observed include the percentage of germination, mean germination time (days), germination rate, optimum temperature of germination, and determination of $\mathrm{PV}$, MDG, and GV. Observation of the germination rate was done since the corn seeds were planted until the seeds reach the highest percentage of germination. The purpose of the germination rate observation is to determine the strength of seeds for germination and its viability. Hartmann et al. (2011) explain that the germination rate in a curve covers 2 patterns of germination increase namely incremental increase and sloping or horizontal increase. The incremental increase is to get the peak value (Peak Value = PV). While the sloping or horizontal increase is to get the Mean Daily Germination value (MDG). PV is the highest point on the germination curve with high percentage of germination, that be reached in the short time of germination. MDG is average the percentage of 
germination per day. Germination Value (GV) are germinability of seeds consist of strength and viability of seeds. That is a value as multiply between MDG and PV.

For seedling research, seeds were planted in polybags containing planting media consisting of a mixture of soil, sand, and manure with a ratio of 1: 1: 1 . The researcher prepared 100 polybags for each cultivar with two seeds in each polybag. Seed was sown of $1 \mathrm{~cm}$ in deep of planting media. If one seed has grown, another seed was removed, thus, it only left one seedling for observation. The polybags were placed in a nursery house because its environmental condition is quite similar to the field conditions. The seedlings were watered every day to maintain its moisture and avoid drought.

The study of seedling growth used a Completely Randomized Design with 4 replications in which each repetition used 4 seedlings. The observation of the seedling growth was carried out in 3 periods, 1 week after planting (wap), 2 wap, and 3 wap. The observation parameters were the number of leaves, leaf color, leaf length $(\mathrm{cm})$, leaf width $(\mathrm{cm})$, chlorophyll content, number of roots, root length, mesocotyl length, seedling fresh weight (gram), and seedling dry weight (gram). Chlorophyll content in seedling leaves was counted by Chlorophyll Meter type 502Plus automatically. All collected data were analyzed using SAS Version 9.1 and presented in tables, graphs, histograms, and figures.

\section{Observation and data collection}

The number of seeds that germinate was counted every day starting from the first germination day until no more germination (around 6 days). The percentage of germination was based on the following equation proposed by Sutopo (1985).

$$
\mathrm{PG}=\frac{N G S}{N S S} \times 100 \%
$$

\section{Where:}

PG : Percentage of germination

NGS : Number of germinated seeds

NSS : Number of sown seeds

The average number of days needed for germination was based on the following equation which was also proposed by Hartman et al. (2011).

Average number of days $=\frac{N 1 T 1+N 2 T 2+\ldots+N x T x}{\text { Total number of seeds that germinate }}$ Where:

$\mathrm{N}$ : Number of seeds that germinate at a certain time

$\mathrm{T}$ : The total amount of time between the beginning of the test until the end of a certain interval of observation.

The observation on the percentage of germination was to obtain PV and MDG and GV based on the formula proposed by Hartmann et al. (2011). The observation of the relative growth rate was carried out in 3 periods, 1 week after planting (wap), 2 wap, and 3 wap. During each observation, the total dry weight per cultivar of the plant was measured covering the top and the bottom surface of the soil. The calculation of relative growth rate (RGR) is based on the formula (Williams and Joseph 1976) below:

$$
\mathrm{RGR}=\frac{\left(\ln \mathrm{W}_{2}-\ln \mathrm{W}_{1}\right)}{\left(\mathrm{t}_{2}-\mathrm{t}_{1}\right)}
$$

Where:

W : Seedling dry weight (gram)

$\mathrm{T}$ : Time (week)

\section{Environmental condition measurement}

The environmental condition measurement was performed in the germination chamber and nursery house using a thermo-hygrometer and lux meter. The parameters measured covered air temperature, humidity, and light intensity. The measurements were done 3 times a day at 09.00, 13.00, and 15.00 WIB. The result of the measurement is presented in Table 1 .

\section{RESULTS AND DISCUSSION}

\section{Morphology of local corn seeds}

The morphological data of local corn seeds that were used in this study are presented in Table 2. To support the data in this table, the following figure displays the pictures of the three cultivar seeds. Based on Table 2 and Figure 1, morphologically the seed of Entog corn has the smallest size compared to others. It is influenced by genetic factors of each cultivar and the growth environment of the corn. In terms of color, Entog, and Senggani cultivars have the same seed color, 162 Pale Yellow D, while Pangkajene cultivars have 158 Pale Yellow A color. High amylopectin in seeds makes the color white (like milk) (Maruapey 2012). The similar seed color of Senggani and Entog corn occurs because the two cultivars contain a quite similar amylopectin content.

Table 1. Environmental condition of germination facility

\begin{tabular}{lcc}
\hline \multirow{2}{*}{ Parameter } & \multicolumn{2}{c}{ Germination facility } \\
\cline { 2 - 3 } & $\begin{array}{c}\text { Germination } \\
\text { chamber }\end{array}$ & $\begin{array}{c}\text { Nursery } \\
\text { house }\end{array}$ \\
\hline Temperature $\left({ }^{\circ} \mathrm{C}\right)$ & $28-30$ & $31-33$ \\
Humidity $(\%)$ & $56-62$ & $65.5-80$ \\
Light Intensity (lux) & $0 \times 10$ & $446 \times 10-1432 \times 10$ \\
\hline
\end{tabular}

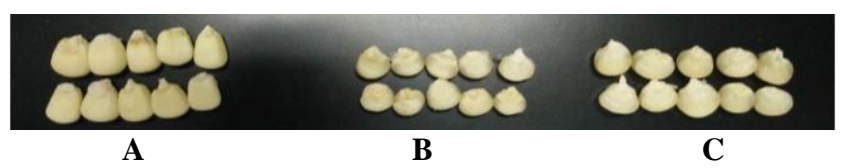

Figure 1. Seeds of 3 local corn cultivars. A. Pangkajene, B. Entog, C. Senggani 
Table 2. Seed characteristics of the 3 local corn cultivars

\begin{tabular}{llll}
\hline Parameter & Pangkajene & Entog & Senggani \\
\hline Weight of 50 fresh seeds & $13.1753 \mathrm{~g}$ & $9.0723 \mathrm{~g}$ & $15.1872 \mathrm{~g}$ \\
Length of seeds & $9.6032 \mathrm{~mm}$ & $7.7025 \mathrm{~mm}$ & $9.1523 \mathrm{~mm}$ \\
Width of seeds & $8.0031 \mathrm{~mm}$ & $8.9535 \mathrm{~mm}$ & $9.5023 \mathrm{~mm}$ \\
Thickness of seeds & $3.6032 \mathrm{~mm}$ & $4.1520 \mathrm{~mm}$ & $4.1521 \mathrm{~mm}$ \\
Shape of seeds & Rounded & Rounded & Rounded \\
Color of seeds & 158 Pale yellow A & 162 Pale yellow D & 162 Pale yellow D \\
\hline
\end{tabular}

Note: Data on seed length, width, thickness, and shape are averages of the 10 measured seeds

Table 3. Moisture content of the three seeds local cultivars

\begin{tabular}{lc}
\hline Cultivar & Moisture content \\
\hline Pangkajene & $2.4230 \%$ \\
Entog & $12.3563 \%$ \\
Senggani & $7.0747 \%$ \\
\hline
\end{tabular}

Generally, seed moisture content affects seed viability and longevity of seed storage while seeding deterioration and aging is a continuous process and its ultimate effects are loss of seed viability and vigor. The seed moisture content of the three local cultivars is presented in (Table 3).

The moisture content of Pangkajene cultivar is very low at around $2.0-2.40 \%$. It has low moisture content because, after the drying, it was packaged in plastic bottles and then stored in dry room temperature for 7 years. Low of moisture content in Pangkajene seeds caused this seed to have high viability although be stored for 7 years. Shaban (2013) said that seeds are characteristically low in moisture and relatively inactive metabolically, which are seed in a state of quiescence. Pangkajene cultivar is originating from a dry area, so that the low seed moisture content does not harm the seeds.

The moisture content of Entog cultivar reaches $12.36 \%$ with 4 months stored that packed in sacks and stored in a warehouse. The uncontrolled temperature and humidity of the warehouse cause the seed moisture content to fluctuate according to the conditions of the storage environment. According to Vertucci (1989) that the seed moisture contents vary continuously according to humidity and temperature of the environment. Extremely low water potential within the dry seeds creates greater affinity for the water molecule to readily absorb by the seeds. Seed moisture isotherms describe equilibrium relationship between the seed moisture contents and equilibrium humidity at a given temperature. The harvested seeds at the end of the dry season (August) are stored in the rainy season, so condensation occurs on the surface of the seeds. Therefore, the surface of the seeds contains a lot of water vapor which is eventually absorbed again by the seed coat; thus, the moisture content of the seeds increases (Sutopo 1985). The moisture content of Senggani cultivar reaches $7.15 \%$ with 1 week stored in a plastic bag. It has low moisture content because the seeds are harvested exceeds the time of physiological maturity by allowing the corncob to dry on the stems for several weeks in the fields. Akhtaruzzaman et al. (2017) said that corn seed in maintaining under $14 \%$ moisture content to keep free from microbial infection. The difference in moisture content in the three local corn cultivars is affected by improper harvest time, drying, packing, and storage system of seeds. Although in this study are found the difference of seed age as follows Pangkajene seeds 7 years, Entog seeds 4 months, and Senggani seeds only 10 days but all corn seeds still have good viability that is influenced by low seed moisture content. According to Bakhtavar et al. (2019), that high seed moisture content is the major culprit that can speed up the process of seed deterioration.

The tetrazolium test was to measure seed viability indirectly. The tetrazolium test is based on the red color that forms in the seed tissue, especially the embryonic part. Seeds with good viability are indicated with red color when soaked in a tetrazolium salt solution. Conversely, a pale red, white, or colorless indicates the dead seeds.

Based on (Figure 2) showed that all of corn seeds had given reaction to tetrazolium with red color. Pangkajene and Entog seeds obtained red color that covers all parts of embryo therefore value of seed viability around $90 \%$. While seeds of Senggani had red color that covers only $70 \%$ of embryo part therefore value of seed viability of Senggani seeds around $70 \%$. The red color is the color of formazan. It is formed from the reaction between 3,3,5 triphenyl tetrazolium chloride (TTC) with the dehydrogenase enzyme in seed tissue. The intensity of the red color in the embryonic tissue indicates the viability of the tissue. Franca-Neto and Krzyzanowski (2019) state the cellular level. Non-viable seed tissues do not react with TTC and consequently do not stain. Therefore can be said that seeds of Pangkajene and Entog have higher viability compared to seeds of Senggani. The correctness of this statement will be proved by direct viability test trough seed germination test.

\section{Seed germination}

\section{Percentage of germination}

The percentage of germination of the three cultivars is relatively high as it is higher than $80 \%$ both germinated in the germination chamber and nursery house. The difference in seed moisture content does not seem to affect the percentage of germination. Data on local corn seed germination is presented in Table 4. 


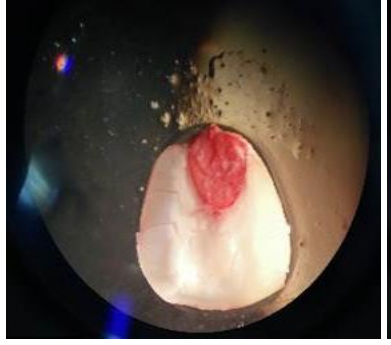

A

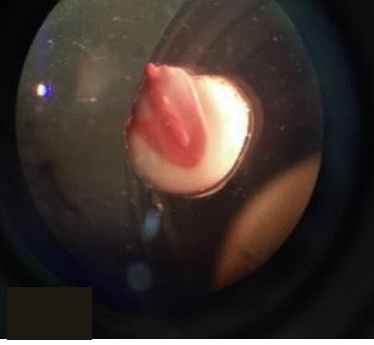

B

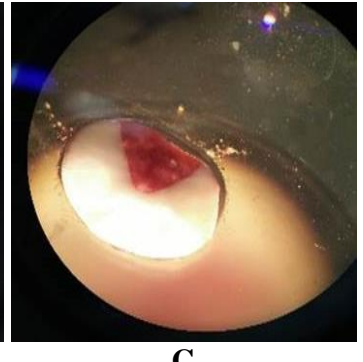

C

Figure 2. Tetrazolium coloring on embryo part of local corn seeds. Note: A. Pangkajene, B. Enthog, C. Senggani

Table 4. The response of cultivars and germination facility on percentage of germination

\begin{tabular}{lclc}
\hline Cultivar & $\begin{array}{c}\text { Percentage } \\
\text { of } \\
\text { germination }\end{array}$ & Germination facility & $\begin{array}{c}\text { Percentage } \\
\text { of } \\
\text { germination }\end{array}$ \\
\hline Pangkajene & $99.50 \mathrm{a}$ & Germinator chamber & $94.33 \mathrm{~b}$ \\
Entog & $99.00 \mathrm{a}$ & Nursery house & $98.33 \mathrm{a}$ \\
Senggani & $90.50 \mathrm{~b}$ & & \\
\hline
\end{tabular}

Note: Numbers are followed by the same letter in one column mean are not significantly different on Duncan Test at level 0.05 .

Table 5. The response of cultivar interaction with germination facility on percentage germination

\begin{tabular}{clc}
\hline Germination facility & Cultivar & $\begin{array}{c}\text { Percentage of } \\
\text { germination } \\
(\%)\end{array}$ \\
\hline Germination Chamber $\left(28-30^{\circ} \mathrm{C}\right)$ & Pangkajene & $100.0 \mathrm{a}$ \\
& Entog & $98.00 \mathrm{a}$ \\
& Senggani & $85.00 \mathrm{~b}$ \\
Nursery House $\left(31-33^{\circ} \mathrm{C}\right)$ & Pangkajene & $99.0 \mathrm{a}$ \\
& Entog & $100.0 \mathrm{a}$ \\
& Senggani & $96.0 \mathrm{a}$ \\
\hline
\end{tabular}

Note: Numbers are followed by the same letter in one column mean are not significantly different on Duncan Test at level 0.05 .

Table 4 shows that the percentage of germination of the three local corn cultivars is relatively high. Pangkajene and Entog cultivars have the highest percentage of germination are $99.5 \%$ and $99.0 \%$. It shows significant differences with Senggani cultivars with percentage of germination is $90.5 \%$. Pangkajene cultivar has a high percentage of germination as it contains high amylopectin that is easily processed into amylose which used in the germination process. Buleon et al (1998) explain that's amylopectin is a polysaccharide which is one of the most dominant molecules of starch in plants, other than maylose. Tako et al. (2014) said that starch consists of amylose and branched amylopectin molecules in molar ratios of $15-25 \%$ and 85 $75 \%$, respectively. The difference of percentage germination on three corn seeds cultivars was influenced by genetic factors that it has in each cultivar. FAO (2018) has set seed quality standards which state that quality seeds have a minimum of $80 \%$ of germination percentage. Base on FAO (2018) statement is meant that three corn seeds cultivars that used as research material have a good seed quality. In this study also showed that tetrazolium test as indicator for result will be reached by germination test.

Other indicators observed in this study were temperature, humidity, and light intensity in the germination facility. The temperature in the nursery house is slightly higher at $31-33^{\circ} \mathrm{C}$, while in the germination chamber, it ranges between $28-30^{\circ} \mathrm{C}$. Based on Table 4 , the seeds germinated in the nursery house and the germination chamber have significantly different results, $94.33 \%$, and $98.33 \%$. In other words, the temperature of germination facility affects corn seed germination. Although the analysis of main and second factors (Table 4) have significant differences in the percentage of germination, thus possibly there is an interaction between the two factors which provides higher results. Data on cultivar interaction with germination facility are presented in Table 5.

Based on Tabel 5, slightly lower temperature of 28$30^{\circ} \mathrm{C}$ affects the percentage germination of Senggani corn seed therefore Senggani cultivars require higher temperatures of $31-33^{\circ} \mathrm{C}$ to achieve the maximum percentage of germination. Pangkajene and Entog cultivars have a wider temperature range between $28-33^{\circ} \mathrm{C}$ to achieve maximum germination. Temperature affects seed germination as it influences water uptake and all metabolic activities of the seeds (Adriance and Brison 1967). Gardner et al. (1995) explain that germination involves metabolic processes in enzyme controlled that are highly responsive to temperature.

\section{Mean germination time}

The time required for seed germination is calculated from seed sowing until the highest percentage of germination. The germination time is affected by cultivars and germination facility. Based on Table 6 , there is a realtime difference between the time needed for seed germination. Senggani cultivar takes 5-6 days and is significantly different from the Entog cultivars to achieve maximum germination. Pangkajene and Entog cultivars require 4-5 days. The response of the germination chamber and the nursery house to the germination time is not significantly different between 4-5 days. The relatively low-temperature difference provides no significant effect on germination time, probably the germination time be affected by the interaction of the cultivars and germination facility as presented in (Table 7). 
The mean germination time required of the three local cultivars in the germination chamber ranges from 4.0-5.0 days and there is no significant difference between the three cultivars. The germination in nursery houses requires 5.0-6.0 days and there is a significant difference between Pangkajene and Senggani cultivars with 4.25 days and 5.75 days respectively.

Based on Table 7, Pangkajene and Entog cultivars can germinate at $28-30^{\circ} \mathrm{C}$ and $31-33^{\circ} \mathrm{C}$ with a high percentage of germination without significant difference requiring 5.0 days germination. It means that Pangkajene and Entog cultivars have optimum temperatures in the temperature range of $28-33^{\circ} \mathrm{C}$. However, Senggani cultivar has a high percentage of germination $(96.0 \%)$ in a nursery house with a germination time of 5.75 days and significantly different if grown in a germination chamber requiring 5.0 days. It indicates that Senggani cultivars have optimum temperatures in the range between $31-33^{\circ} \mathrm{C}$. The interesting symptom of Senggani cultivar is that it has high percentage of germination at high temperatures but it requires a longer germination time of 1 day. Copeland \& Mc Donald (2001) explained that seed of cereal crops will germinate on optimum temperature around $15-30^{\circ} \mathrm{C}$ and maximum temperature about $30-40^{\circ} \mathrm{C}$. The optimum temperature may be defined as the temperature giving the greatest percentage of germination in the shortest time. The maximum temperature is governed by the temperature at which denaturation of proteins essential for germination occurs (Shaban 2013). Determination of the optimum temperature for corn plants is important as an indicator of vegetative growth in the garden. In addition to genetic trait controls, the favorability of a cultivar at optimum temperature, and also is affected by the certain habitat of plant as seed source location.

\section{Germination rate}

Germination process will be started from water imbibition by seed coat and be followed by plumula and radicle emergence through seed coat and grow as young plant (seedling). Figure 3 shows the seed germination rate of 3 local cultivars in the germination chamber.

The germination rate of the three cultivars grown in the germination chamber shows that the percentage increase occurs at the transition between the second to the third day

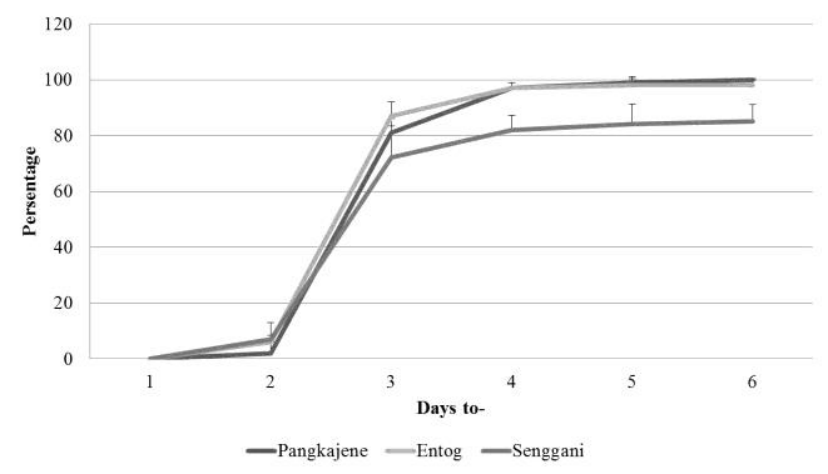

Figure 3. Curve of the corn seed germination rate in germination chamber for Pangkajene (81\%), Entog (87\%), and Senggani (72\%). Hartmann et al. (2011) state that the point when it reaches the highest germination rate is referred to as the Peak Value (PV). The peak values for the three cultivars are Pangkajene 27, Entog 29, and Senggani 24. Furthermore, the germination curve began to the slope and flatten on the third day to the sixth day by reaching the highest germination percentage for Pangkajene (100\%), Entog (98\%), and Senggani (85\%). The mean daily germination (MDG) for each cultivar is $16.66 \%, 16.33 \%$, and $14.16 \%$ for Pangkajene, Entog, and Senggani respectively (Table 8 ). The interesting phenomenon is that the three cultivars reach peak values on the same day, the third day. It is because these three cultivars have high germinability and are supported by a stable germination chamber so that they give the same and fast reaction. Figure 4 shows the curve of the local corn germination rate in nursery houses.

Table 6. The response of cultivar and germination facility on germination speed (days)

\begin{tabular}{lclc}
\hline \multicolumn{1}{c}{ Cultivar } & $\begin{array}{c}\text { Germination } \\
\text { time }\end{array}$ & \multicolumn{1}{c}{$\begin{array}{c}\text { Germination } \\
\text { facility }\end{array}$} & $\begin{array}{c}\text { Germination } \\
\text { time }\end{array}$ \\
\hline Pangkajene & $4.62 \mathrm{ab}$ & Germinator chamber & $4.75 \mathrm{a}$ \\
Entog & $4.50 \mathrm{~b}$ & Nursery house & $4.92 \mathrm{a}$ \\
Senggani & $5.38 \mathrm{a}$ & & \\
\hline
\end{tabular}

Note: Numbers are followed by the same letter in one column mean are not significantly different on Duncan Test at level 0.05.

Table 7. The response of cultivar interaction with germination facility on mean germination speed (days)

\begin{tabular}{llcc}
\hline $\begin{array}{c}\text { Germination } \\
\text { facility }\end{array}$ & Cultivar & $\begin{array}{c}\text { Mean } \\
\text { germination } \\
\text { time }\end{array}$ & $\begin{array}{c}\text { Maximum } \\
\text { germination } \\
\text { percentage (\%) }\end{array}$ \\
\hline $\begin{array}{l}\text { Germination } \\
\text { chamber }\end{array}$ & Pangkajene & $5.00 \mathrm{ab}$ & $100.0 \mathrm{a}$ \\
$\left(28-30^{\circ} \mathrm{C}\right)$ & Entog & $4.25 \mathrm{~b}$ & $98.00 \mathrm{a}$ \\
& Senggani & $5.00 \mathrm{ab}$ & $85.00 \mathrm{~b}$ \\
Nursery house & Pangkajene & $4.25 \mathrm{~b}$ & $99.00 \mathrm{a}$ \\
$\left(31-33^{\circ} \mathrm{C}\right)$ & Entog & $4.75 \mathrm{ab}$ & $100.0 \mathrm{a}$ \\
& Senggani & $5.75 \mathrm{a}$ & $96.00 \mathrm{a}$ \\
\hline
\end{tabular}

Note: Numbers are followed by the same letter in one column mean are not significantly different on Duncan Test at level 0.05.

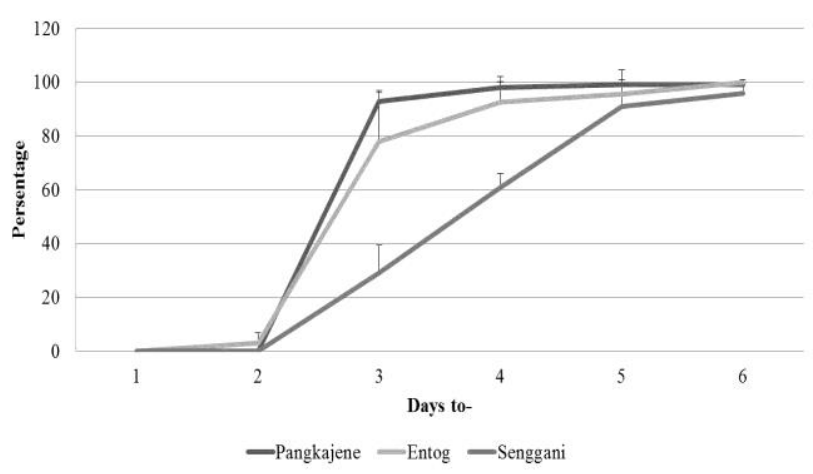

Figure 4. Curve of corn seed germination rate in nursery house 
Referring to Hartmann et al. (2011), the germination rate of Pangkajene and Entog cultivars reach peak values on the third day with values of 31 and 26 of each. Senggani cultivars reach peak values on the fifth day with a value of 18.2. The mean daily germination (MDG) of the three cultivars is $16.50 \%$ for Pangkajene, $16.66 \%$ for Entog, and $16.00 \%$ for Senggani. The Peak value difference of three corn seeds cultivars on two germination facilities with different temperatures showed that every corn seed cultivar gives respond to temperature for germination is not similar because every corn cultivar has difference of genetics factors.

The Germination Value $(\mathrm{GV})$ is the multiplication result of peak values (PV) and mean daily germination (MDG) (Hartmann et al. 2011). The germination value is to assess the quality of a variety or cultivar compared to others during the test. If the germinated or tested seed is only one variety or cultivar, then the germination value cannot be compared. The germination values of the three cultivars are presented in Table 8. Based on this table, Pangkajene and Entog cultivars have a higher Germination Value compared to the Senggani cultivar. Thus, it can be said that the seeds quality of Pangkajene and Entog cultivar is better than Senggani's.

\section{Seedling growth}

Seedling is defined as a complete germination process after the emerge of radicals and plumules through the seed coat and it grows into young plants with roots and leaves (Adriance and Brison 1967). Salisbury and Ross (1992) explain that after germination, plant development is further controlled by light.

\section{Seedling leaf}

At first, the seedling leaves were covered by coleoptiles and coleoptiles grow faster than the wrapped leaves. Thus, the leaves grew safely over the surface of the soil. After the coleoptiles were exposed to light, seedling leaf growth begins immediately (Salisbury and Ross 1992). The following data show the number and the size of leaves, chlorophyll content, and leaf color. The number of seedling leaves of these three local cultivars from 1, 2, and 3 wap (week after planting) is showed in Figure 5.

Statistically, the number of seedling leaves of 3 local cultivars is not significantly different in the first and the third week. Based on Figure 5, Pangkajene cultivars tend to have more leaves compared to Entog and Senggani, particularly in the $3^{\text {rd }}$ week of wap. The leaf growth of corn is more affected by genetics and light (Salisbury and Ross 1992). In this study, all three cultivars were in one location (in the nursery house), thus the insignificant difference in the number of leaves might be controlled by genetic factors. Leaf sizes at the seedling level of the three local cultivars are presented in Table 9.

Leaf length in the first week (1 wap) is not significantly different among the three cultivars. In the second ( 2 wap) and third week ( 3 wap), the shortest leaf length was found in Entog cultivars and significantly different from Pangkajene and Senggani cultivars. It is because Entog cultivar seeds are small so that the scutellum is also small.
In the first week, the number of leaves is still small, thus the leaf growth can still be supplied with food from scutellum. Therefore, the leaf length is not significantly different from Pangkajene and Senggani cultivars. In the $2^{\text {nd }}$ and $3^{\text {rd }}$ wap, the number of leaves increases as well as other parts such as roots and others. It requires more food supply for growth; thus the small scutellum cannot supply foods. It makes the growth significantly lower than Pangkajene and Senggani cultivars. Leaf width growth was not significantly different among the three cultivars and at all age levels of seedlings.

Table 8. Germination values of the three local corn cultivars

\begin{tabular}{lllll}
\hline $\begin{array}{c}\text { Germination } \\
\text { facility }\end{array}$ & Cultivar & $\begin{array}{c}\text { Peak } \\
\text { values }\end{array}$ & MDG & GV \\
\hline Germination \\
chamber & Pangkajene & 27.00 & 16.66 & 448.20 \\
& Entog & 29.00 & 16.33 & 473.57 \\
& Senggani & 24.00 & 14.16 & 339.84 \\
& Mean & & & 420.54 \\
Nursery house & Pangkajene & 31.00 & 16.50 & 511.50 \\
& Entog & 26.00 & 16.66 & 433.16 \\
& Senggani & 18.20 & 16.00 & 291.20 \\
& Mean & & & 411.95 \\
\hline
\end{tabular}

Table 9. Size of seedling leaf of the three local corn cultivars

\begin{tabular}{lllllll}
\hline \multirow{2}{*}{ Cultivar } & \multicolumn{3}{c}{ Length } & \multicolumn{3}{c}{ Width } \\
\cline { 2 - 7 } & 1 wap & 2 wap & 3 wap & 1 wap & 2 wap & 3 wap \\
\hline Pangkajene & 7.33 a & $37.15 \mathrm{a}$ & $59.95 \mathrm{a}$ & $1.68 \mathrm{a}$ & $1.40 \mathrm{a}$ & $2.25 \mathrm{a}$ \\
Entog & $5.58 \mathrm{a}$ & $29.78 \mathrm{~b}$ & $47.05 \mathrm{~b}$ & $1.58 \mathrm{a}$ & $1.48 \mathrm{a}$ & $2.20 \mathrm{a}$ \\
Senggani & $7.20 \mathrm{a}$ & $39.40 \mathrm{a}$ & $54.78 \mathrm{a}$ & $1.63 \mathrm{a}$ & $1.65 \mathrm{a}$ & $2.15 \mathrm{a}$ \\
\hline
\end{tabular}

Note: Numbers are followed by the same letter in one column mean are not significantly different on Duncan Test at level 0.05.

Table 10. Chlorophyll content in the leaves of three local corn cultivars

\begin{tabular}{llll}
\hline Cultivar & 1 wap & 2 wap & 3 wap \\
\hline Pangkajene & $51.28 \mathrm{a}$ & $45.62 \mathrm{ab}$ & $42.08 \mathrm{~b}$ \\
Entog & $49.6 \mathrm{ab}$ & $41.65 \mathrm{~b}$ & $41.76 \mathrm{~b}$ \\
Senggani & $45.45 \mathrm{~b}$ & $47.81 \mathrm{a}$ & $44.85 \mathrm{a}$ \\
\hline
\end{tabular}

Note: Numbers are followed by the same letter in one column mean are not significantly different on Duncan Test at level 0.05 .

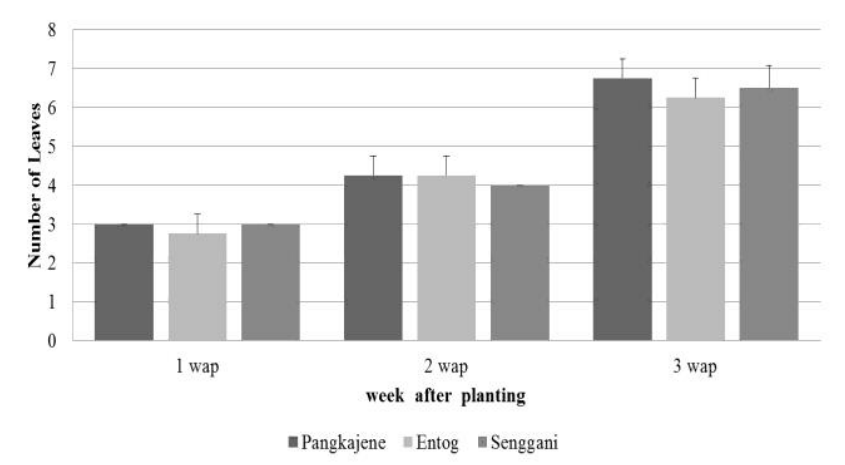

Figure 5. The number of seedling leaf of local cultivars in 1, 2, and 3 wap 
In this study, we observed the content of chlorophyll in leaves of corn seedling. Brown (1973) explains that chlorophyll is not a single compound but a mixture of various pigmentary structures such as green pigments called chlorophyll $\mathrm{a}$ and $\mathrm{b}$ and yellowish-brown pigments such as carotene and xanthophyll. In plants, chlorophyll molecules harvest light in the process of photosynthesis and furthermore converts light energy into chemical energy (Milodzinski 2009). Several factors affecting the formation of chlorophyll in plant leaves cover carbohydrates, oxygen, magnesium, and other ions (Peng et al. 2019) therefore Brown (1973) describes that chlorophyll formed in flowering plants due to the presence of sunlight. $\mathrm{He}$ explains that chlorophyll does not contain iron, but this element is required for the formation of chlorophyll. Observation of chlorophyll content in seedling leaves was done every week as presented in Table 10.

The chlorophyll content of the seedling leaf of 3 cultivars in 3 weeks shows a varied number but the pattern always decreases from the first to the third week after planting. The decrease in chlorophyll content is possibly due to light intensity in the nursery house which is still low at 950x10 lux. Thus, it cannot stimulate pigmentary tissue to form chlorophyll granules. In the third wap, the Senggani cultivar had greater chlorophyll content and was significantly different from the other two cultivars. It is maybe affected by genetic factors of each of local cultivar. According to Dwijoseputro (1978), the presence of chlorophyll in plant leaves is inherited by genes in chromosome. Thus, the amount of chlorophyll in leaves of each local corn seedling is different. Ndukwe et al. (2016) compounded that the chlorophyll concentration differed among the variety of the maize leaves. According to Shaikh and Dongare (2008) that chlorophyll and carotenoids contents varied with microclimatic conditions in Adiantum species. Therefore either biotic or abiotic factors can induce stress in a plant affecting specific processes on individual leaves resulting in both a loss of chlorophyll and a change in its distribution pattern (Barton 2000). Based on Figure 6, the color of the seedlings of three cultivars in the $1^{\text {st }}$ week of wap is moderate yellow-green and switches to moderate olive-green in the $3^{\text {rd }}$ week of wap.

The color transition from yellow to dark green indicates that the presence of light in the nursery house affects the leaf color. If the leaves are exposed to sunlight in longer time consequently leaf color will turn dark green (Salisbury and Ross 1992). The need for sunlight will always increase according to the age of the seedlings. Furthermore, the seedlings grow and develop; they will have more complete plant parts. In its growth and development, seedlings or plants need sunlight to carry out the assimilation process and other growth processes. According to Dwijoseputro (1978), the plant leaves contain 2 kinds of chlorophyll, namely chlorophyll a with dark green color and chlorophyll b with yellowish-green. Besides color, that the other difference between chlorophyll a and $b$, be on basic structure of chlorophyll molecules are chlorophyll a contains a methyl group while chlorophyll b contains a formyl moiety (Miazek and Ledakowicz 2013). Probably on 1 wap, the leaves of corn seedling contain a great amount of chlorophyll b. Therefore, the color of corn seedling is moderate yellow-green but on 2 and 3 wap, the leaves of corn seedling occurred lowering of chlorophyll $b$ content and increase of chlorophyll a, causing the leaves color of corn seedling change to moderate olive green (Figure 6). Miazek and Ledakowicz (2013) compounded that chlorophyll absorbs light in the red and the blue-violet regions of solar spectrum but green light is not absorbed and reflected giving chlorophyll its green color.

\section{Seedling root}

The growth of corn seedling roots from the three cultivars during the first to the third week after planting is presented in Table 11. Based on this table 11, Pangkajene cultivar has more root growth starting from the first to the third week after planting and it is significantly different from the other cultivars from Purbalingga. This difference is highly affected by genetic factors. There is a tendency for the number of roots in the Entog cultivar to be lower than the other two cultivars because this cultivar has a smaller seed size than the others. Therefore Queiroz et al. (2019) describe that differences in seed size affect the amount of amylum and other nutrients in the seeds that can affect on germination process and seedling growth. Salisbury and Ross (1992) state that the growth of leaves and roots at the seedling level still comes from food reserves in scutellum. They both added that the growth of leaves, chlorophyll, and roots are also affected by light. In the first week after planting, the seedling root length is significantly different between $10-11 \mathrm{~cm}$ for all corn cultivars as presented in Table 12.

In the $2^{\text {nd }}$ and $3^{\text {rd }}$ weeks after planting, the root of Pangkajene seedlings is longer and significantly different than the other two local corn from Purbalingga. This difference is more affected by genetic factors possessed by each cultivar.

Table 11. Number of roots in local corn seedling

\begin{tabular}{llll}
\hline Cultivar & 1 wap & 2 wap & 3 wap \\
\hline Pangkajene & $3.00 \mathrm{a}$ & $6.25 \mathrm{a}$ & $9.75 \mathrm{a}$ \\
Entog & $1.75 \mathrm{~b}$ & $4.50 \mathrm{~b}$ & $7.25 \mathrm{~b}$ \\
Senggani & $3.00 \mathrm{a}$ & $5.13 \mathrm{a}$ & $7.00 \mathrm{~b}$ \\
\hline
\end{tabular}

Note: Numbers are followed by the same letter in one column mean are not significantly different on Duncan test at level 0.05 .

Table 12. Length of seedling roots of local corn cultivars in 1, 2, and 3 wap

\begin{tabular}{lccc}
\hline Cultivar & 1 wap & 2 wap & 3 wap \\
\hline Pangkajene & $10.36 \mathrm{a}$ & $11.78 \mathrm{a}$ & $18.49 \mathrm{a}$ \\
Entog & $10.51 \mathrm{a}$ & $10.64 \mathrm{a}$ & $13.68 \mathrm{~b}$ \\
Senggani & $10.96 \mathrm{a}$ & $8.43 \mathrm{~b}$ & $12.43 \mathrm{~b}$ \\
\hline
\end{tabular}

Note: Numbers are followed by the same letter in one column mean are not significantly different on Duncan test at level 0.05 


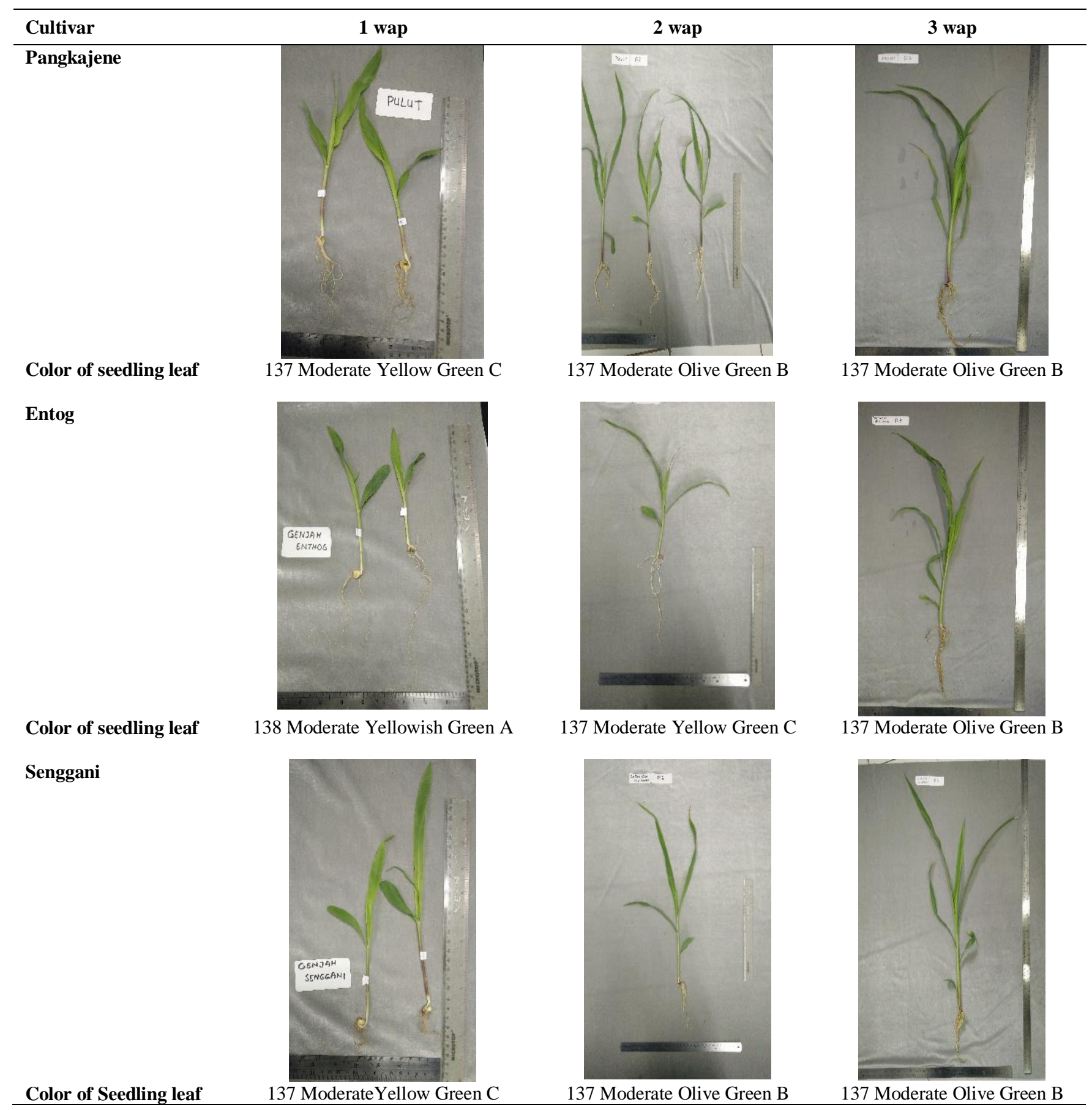

Figure 6. Seedling of the three cultivars of 1, 2, and 3 wap and the color of seedling leaf

\section{Mesocotyl internode}

Commonly, mesocotyl internode is found in the Poaceae plant, which is the first node (above of scutellum) between and the second node (base of coleoptile) (Salisbury and Ross 1992). Coleoptile base is a second node that is a place to grow wild roots further in which the roots grow into supporting roots as in corn and sorghum. The length of the mesocotyl internodes can be used as a characteristic of a variety or cultivar. Elongation of the mesocotyl internode from the first to the third week after planting of the three cultivars is presented in the histogram in Figure 6.

The length of the seedling mesocotyl internode of the three cultivars from the first to the third week after planting was found significantly different. The mesocotyl internode in Entog and Senggani cultivars tended to be longer than the mesocotyl internode of the Pangkajene seedling. The elongation of the mesocotyl internode is to encourage coleoptiles and leaf buds to immediately get sunlight (Salisbury and Ross 1992) while according to Zhao and 
Wang (2010) that the maize mesocotyl elongation is more sensitive to $\mathrm{GA}_{3}$ under $20 \mathrm{~cm}$ deep-sowing than under $2 \mathrm{~cm}$ shadow-sowing. In this study, the depth of seed sowing in planting media were same about $1 \mathrm{~cm}$. Therefore, the difference in the length of the mesocotyl internode in the three cultivars is affected by genetic factors of each cultivar. Although the critical genes determining mesocotyl elongation in maize remain unknown (Niu et al. 2019). Dubois et al. (2010) compounded that has occurred the role of interactions between $\mathrm{ABA}$ and $\mathrm{GA}_{3}$ hormones in mesocotyl elongation especially for maize seedling growth in temperate region. The size of the mesocotyl internode becomes an indicator of the height of the stem that will grow and as a promising selection organ for evaluation stress tolerance at the early seedling stage (Niu et al. 2019).

\section{Relative growth rate}

Relative Growth Rate (RGR) symbolized by the letter ' $R$ ' is the addition of plant weight due to growth in one unit of time. The study of RGR used dry weight, but it is important to find fresh weight data first. The observed fresh weight of the seedlings covers all parts of the seedlings consisted of seedling leaves and roots. Observational data are presented in (Tables 13 and 14).

Based on (Table 13), the lowest fresh seedling weights are found in Entog seedlings. In the second and third weeks after planting, the fresh weight of the Entog cultivar seedling is lower and significantly different from the fresh weight of the Senggani seedling but was not different from Pangkajene cultivar. The difference in fresh weight is affected by genetic factors possessed by each cultivar. Physiologically, the small seed size of Entog cultivar influences the growth of seedling leaves and roots which ultimately affects the fresh and dry weight of the seedlings as listed in (Table 14). This idea in line with Queiroz et al. (2019) describes that differences in seed size affect the amount of amylum and other nutrients in the seeds that can influence to germination process and seedling growth.

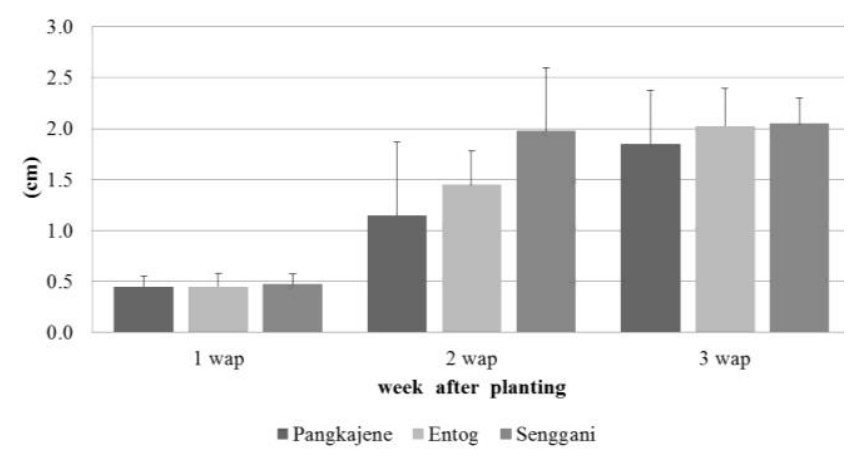

Figure 7. Length of local corn root mesocotyl internodes on the 1, 2 , and 3 wap
The relative growth rate indicates the ability of plants to produce dry materials at a certain period of growth. At the seedling level, the seedling weight is always calculated in grams while the time is in week. An increase in the relative growth rate will increase if the dry weight of the plant increases. Meanwhile, the low in total dry weight indicates the reduction of relative growth rate (Takano et al. 2016).

The relative growth rate of local cultivars at 2 different times, namely R1 and R2 showed an increase. R1 is the relative growth rate of seedlings from the first to the second week after planting. Then, $\mathrm{R} 2$ is the relative growth rate of seedlings from the first to the third week after planting. The increase in the relative growth rate of each cultivar is also affected by environmental factors, particularly growth media and sunlight. In this research, Pangkajene and Senggani cultivars have higher relative growth values (R1 and R2) compared to Entog. This means that the growth of Pangkajene and Senggani cultivars seedlings is more active than Entog seedlings.

Table 13. Fresh weight of seedlings in 1, 2, and 3 wap

\begin{tabular}{llll}
\hline Cultivar & 1 wap & 2 wap & 3 wap \\
\hline Pangkajene & $0.90 \mathrm{a}$ & $2.28 \mathrm{~b}$ & $7.79 \mathrm{ab}$ \\
Entog & $0.52 \mathrm{~b}$ & $2.08 \mathrm{~b}$ & $6.48 \mathrm{~b}$ \\
Senggani & $0.58 \mathrm{~b}$ & $3.43 \mathrm{a}$ & $9.14 \mathrm{a}$ \\
\hline
\end{tabular}

Note: Numbers are followed by the same letter in one column mean are not significantly different on Duncan test at level 0.05 .

Table 14. Dry weight of seedlings in 1, 2, 3 wap and values of R1 and R2

\begin{tabular}{lccccc}
\hline Cultivar & 1 wap & 2 wap & 3 wap & $\begin{array}{c}\text { Values } \\
\text { of R1 }\end{array}$ & $\begin{array}{c}\text { Values } \\
\text { of R2 }\end{array}$ \\
\hline Pangkajene & $0.12 \mathrm{a}$ & $0.30 \mathrm{a}$ & $0.98 \mathrm{a}$ & 0.096 & 0.219 \\
Entog & $0.08 \mathrm{~b}$ & $0.20 \mathrm{~b}$ & $0.71 \mathrm{~b}$ & 0.062 & 0.159 \\
Senggani & $0.11 \mathrm{a}$ & $0.32 \mathrm{a}$ & $0.94 \mathrm{a}$ & 0.106 & 0.209 \\
\hline
\end{tabular}

Note: Numbers are followed by the same letter in one column mean are not significantly different on Duncan test at level 0.05 .

$\mathbf{E}$

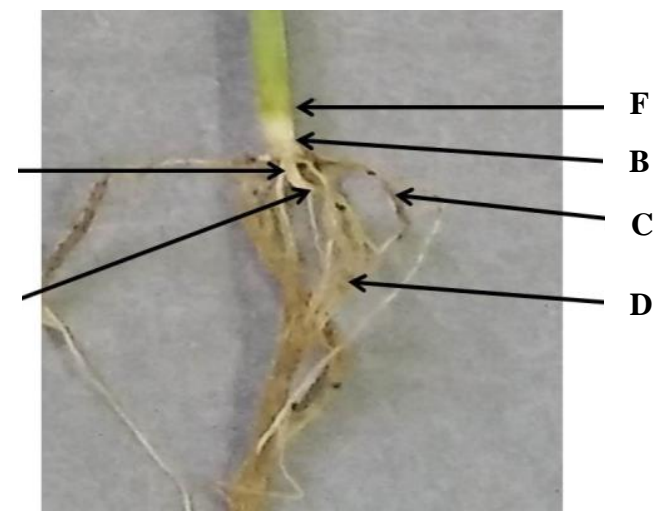

Figure 8. Root system of corn seedlings. A. First node, B. Second node, C. Wild roots, D. Primary root, E. Mesocotyl internode, F. Coleoptile 
Maruapey (2012) states that differences in morphological characters in seedlings/plants are caused by differences in genes that regulate the characters. Diverse genes from each cultivar are expressed in a variety of morphological characters. Entog seedlings have a small seedling morphology because they come from smaller corn seeds compared to other cultivars. Small seeds will produce a low dry weight of seedling (Tables 13 and 14). Based on the number, length, and width of leaves, genetically Pangkajene cultivars have the largest size (Figure 4 and Table 9). Maruapey (2012) states that the leaf size and the number of leaves affect the maximum reception and absorption of sunlight. The maximum absorption of sunlight followed by optimal absorption of nutrients will support the photosynthesis process that can stimulate plant growth.

The result of this study showed that Pangkajene and Entog cultivars have higher germinability seeds compared to Senggani cultivars. Besides, that be also known that Pangkajene and Senggani cultivars have higher seedling growth than Entog cultivar seedlings characterized by a higher relative growth rate $(\mathrm{R})$ value. Therefore, it can be concluded that Pangkajene Cultivars from South Sulawesi have higher quality compared to Entog and Senggani cultivars from Purbalingga, Central Java, and Senggani cultivars have higher quality than Entog cultivars.

\section{REFERENCES}

Adriance GW, FR Brison. 1967. Propagation of Horticultural Plants. 2nd ed. The McGraw Hill Book Company Inc., New York.

Akhtaruzzaman Md, Sohany M, Basunia MA, Hossain MdK, Sarker MdSH. 2017. Drying and quality features of selected maize varieties dried in commercial processing complexes. Agric Eng Intl 19 (3): 148-155.

Bakhtavar MA, Afzal I, Basra SMA. 2019. Moisture adsorption isotherms and quality of seeds stored in conventional packaging materials and hermetic super bag. PLoS One 14 (2): e0207569. DOI 10.1371/journal.pone.0207569.

Barton CVM. 2000. A theoretical of the influence of heterogeneity in chlorophyll distribution on leaf reflectance. Tree Physiol 21: 789-795.

Brown WH. 1973. The Plant Kingdom. A Textbook of General Botany. Ginn And Company, Lexington, MS, USA.

Buleon A, Colonna P, Planchot V, Ball S. 1998. Mini review. Starch granules: structure and biosynthesis. Intl J Biol Macromol 23: 85-112.

Copeland LO, Mc Donald MB. 2001. Principles of Seed Science and Technology. 4th ed. Norwell, MS, USA.

Dubois PG, Olsefski GT, Flint-Garcia S, Setter TL, Hoekenga OA, Brutnell TP. 2010. Physiological and genetic characterization of end of day far-red light response in maize seedlings. Plant Physiol 154: 173-186. DOI: 10.1104/pp.110.159830.

Dwijoseputro D. 1978. Pengantar Fisiologi Tumbuhan. PT Gramedia, Jakarta. [Indonesian]

FAO. 2018. Seeds Toolkit. Module 3: Seed Quality Assurance. Food and Agriculture Organization of the United Nations. Rome, Italy.
Franca-Neto JdB, Krzyzanowski FC. 2019. Tetrazolium: An important test for physiological seed quality evaluation. J Seed Sci 41 (3): 359366.

Gardner FP, Pearce RB, Mitchell RL. 1985. Physiology of Crops Plants Iowa State University Press, Ames, IO.

Hartmann HT, Kester DE, Davies FT, Geneva RL. 2011. Plant Propagation. Principles and Practices. 8th ed. Prentice-Hall, New York.

IBPGR/CIMMYT. 1991. Descriptor for Maize, IBPGR/CIMMYT, Rome.

Maruapey A. 2012. Pengaruh pupuk kalium terhadap pertumbuhan dan produksi berbagai jagung pulut (Zea mays ceratina. L). Ilmiah Agribisnis dan Perikanan 5 (2): 33-45. [Indonesian]

Miazek K, Ledakowicz S. 2013. Chlorophyll extraction from leaves, needles, and microalgae. Intl J Agric Biol Eng 6 (2): 107-115.

Milodzinski E. 2009. Survey of plant pigments: molecular and environmental determinants of plant colors. Acta Biol Cracovienca Ser Bot 51 (1): 7-16.

Ndukwe OK, Edeoga HO, Okwulehie IC, Omosun G. 2016. Variability in the chlorophyll and carotene composition of ten maize (Zea mays) Varieties. Eur J Physic Agric Sci 4 (1): 1-5.

Niu L, Hao R, Wu X, Wang W. 2019. Maize mesocotyl: role in response to stress and deep-sowing tolerance. Plant Breed. DOI: 10.1111/pbr.12804.

Peng YY, Liao LL, Liu S, Nie MM, Li J, Zhang LD, Ma JF, Chen ZC. 2019. Magnesium deficiency triggers S GR-mediated chlorophyll degradation for magnesium remobilization. Plant Physiol 181: 262275.

Queiroz MS, Oliveira CES, Steiner F, Zuffo AM, Zoz T, Vendruscolo EP, Silva MV, Mello BFFR, Cabral RC, Menis FT. 2019. Drought stresses on seed germination and early growth of maize and sorghum. J Agric Sci 11(2): 310-318.

Salisbury FB, CW Ross. 1992. Plant Physiology, Hormones and Plant Regulators Auxins and Gibberellins. 4th ed., Wadsworth Publishing, Belmont, CA.

Shaban M. 2013. Effect of water and temperature on seed germination and emergence as a seed hydrothermal time model. Intl J Adv Biol Biom Res 1 (12): 1686-1691.

Shaikh SD, Dongare M. 2008. Analysis of photosynthesis pigments in Adiantum lunulatum Burm. at different localities of Sindhudurg District Maharastra. India Fern J 25: 83-86.

Sutopo L. 1985. Teknologi Benih. CV. Rajawali, Jakarta. [Indonesian]

Takano HK, RS Oliveira JR, J Constantin, GBP Braz, JC Padoseve. 2016. Growth, development, and seed production of goosegrass. Planta Daninha, Vicosa-MG. 34 (2): 249-257. DOI: 10.1590/S010083582016340200006.

Tako M, Tamaki Y, Teruya T, Takeda Y. 2014. The principles of starch gelatinization and retrogradation. Food Nutr Sci 5: 280-29. DOI: 10.4236/fns.2014.53035

Vertucci CW. 1989. The kinetics of seed imbibition: Controlling factors and relevance to seedling vigor. In: Stanwood PC, McDonald MB (eds.). Seed Moisture. Crop Science Society of America, Madison, WI.

Wawo AH, Silverstone S, Lestari, P. 2018. Growth and yield characteristics of national superior maize variety and local variety in Penjarakan Village, Bali; Proceeding International Symposium on Bioeconomics of Natural Resources utilization (ISBINARU). Bogor, Indonesia. 12-14 October 2018.

Williams CN, Joseph KT. 1976. Climate, Soil and Crop Production in the Humid Tropics. Oxford Univ Press, Kuala Lumpur, New York.

Zhao GW, Wang JH. 2010. Effect of auxin on mesocotyl elongation of dark-grown maize under different seeding depths. Russ J Plant Physiol 57: 79-86. DOI: 10.1134/S1021443710010115. 